\title{
THE IMPACT OF DYSFUNCTIONAL FAMILY ON ADULT CHILD PORTRAYED IN MY NAME IS LUCY BARTON
}

\author{
Annisa Laras Andhika ${ }^{1}$, Swesana Mardiah Lubis ${ }^{2}$, Riko Andika Rahmat Pohan ${ }^{3}$ \\ University of Sumatera Utara, Indonesia \\ larasannisand@gmail.com, 2 swesanalubis1234@gmail.com, ${ }^{3}$ riko@usu.ac.id
}

\begin{abstract}
This article entitled "The Impact of Dysfunctional Family on Adult Child Portrayed in My Name is Lucy Barton "explains the kinds of dysfunctional families and their behavioural impacts on adult children. My Name is Lucy Barton novel was selected because it largely showed the dysfunctional condition and how it impacts adult children. The aim is to find out the kinds of the dysfunctional family and behavioural impacts on adult children. The study uses kinds of dysfunctional family by Hunt, theory of psychoanalysis by Bowen, and behavioural impacts by Martin. The descriptive qualitative method is applied by presenting data in words and sentences. Reading and selecting quotations from novels were done to collect data as library research. The result is the adult child survives from a controlling and chaotic family. Loneliness, hopelessness, insecurity, guilt and being ignored as the impacts of psychological problems were commonly faced by adult children.
\end{abstract}

Keywords: Behavioral Impact; Dysfunctional Family; Adult Children.

\begin{abstract}
ABSTRAK
Artikel ini berjudul "The Impact of Dysfunctional Family on Adult Child Portrayed in My Name is Lucy Barton" membahas tentang dampak keluarga disfungsional pada perilaku anak yang telah dewasa. Novel My Name is Lucy Barton dipilih karena sangat menunjukkan dampak kondisi keluarga disfungsional pada anak yang telah dewasa. Tujuannya untuk mengetahui jenis keluarga disfungsional dan dampak perilakunya pada anak yang telah dewasa. Penelitian artikel ini menggunakan teori jenis keluarga disfungsional June Hunt, psikoanalisis Bowen, dampak perilaku oleh Martin. Metode deskriptif-kualitatif digunakan untuk menunjukkan data dalam bentuk kata dan kalimat. Data dikumpulkan dari hasil membaca dan memilih kutipan novel sebagai riset perpustakaan. Hasilnya anak yang telah dewasa menyelamatkan diri dari keluarga yang terlalu mengendalikan dan kacau balau. Merasa sendirian, putus asa, canggung, bersalah, dan tidak dapat dicintai sebagai dampak permasalahan psikologis yang dialami anak yang telah dewasa.
\end{abstract}

Kata Kunci: Dampak Perilaku; Keluarga Disfungsional; Anak yang telah Dewasa.

\section{INTRODUCTION}

The dysfunctional family is often stigmatized as a broken home family while the actual it is not always sounded as parents are already divorced. There are so many reasons why dysfunctional families can happen, it may be because of economic problems, parents with mental illness, domestic violence, and many more. A family can be categorized as a dysfunctional family when they have all those kinds of problems but parents do not have any 
intention to split up even divorce. So, it may happen to any family at any time. A dysfunctional family can be negatively impacted both parents and children's mental and behavioural style. One of those kinds of problems can be seen from Marshanda, a public figure who is well-known since she was little. She was found out by the public through her video and uploaded it on social media years ago. She screamed out loud, yelling on the video. Her reactions to the video can be categorized as the impact of her experience in her dysfunctional family. The fact is her parents have been divorced some years ago. Marshanda lived with her mother and rarely met her father afterwards. Her mother is a businesswoman and Marshanda herself is an actress. It is clear to know that she rarely interacts with her own family because of her job.

(Bista, 2016) said that adults being raised in dysfunctional families are reported having public mental health issues based on completed studies in the USA and Canada. Take one example in Indonesia, a public figure who is an impacted adolescent in a dysfunctional family, Marshanda. She is an Indonesian actress who started her career when she was a kid. She has experienced a dysfunctional family: her parents divorced since she was a kid. Indeed, as a child who needs her parents' affection, she rarely got it. Then when she started her own family, the accumulation of psychological impacts of dysfunctional families affected her. She has divorced her ex-husband: Ben Kasyafani. Finally, she opens up about her mental illness which is bipolar disorder making her easily denies her feelings and reality and that condition needs serious treatment.

In Indonesia, the case of the dysfunctional family can be seen from Health Policy Unit Consultant in Southeast Asia Mental Health Forum 2018 in Jakarta showing that around $15.8 \%$ of families in Indonesia have a mental illness. Another data taken from Woman National Commission Annual Notes in Courts data showing that around 335,062 cases of domestic violence that lead to divorce. To understand more how dysfunctional families impact children's behaviour, we may see it from literary works such as novels, short stories, poetry and many more. Considering the society nowadays, the psychological condition of someone from their behaviour in this present day, our history and many more through literary works. Literature shows how humans behave in facing problems and the environment. As (Ahmadi, 2015) explained "Literature represents human actions to reach appetite. We can understand someone's psyche through literature and understand psychology through literature. Because of that, literature relates to psychology and psychology helps to clarify some literary problems".

Dysfunctional family cases are often found in this modern era. Even some authors are interested in making this topic into a novel. One of them is Elizabeth Strout in her novel entitled My Name is Lucy Barton. The author is an American novelist. She is also pronounced as the winner of the Pulitzer Prize for Fiction of her works Olive Kitteridge (2008). While years later she wrote her novel My Name is Lucy Barton is published in 2016 and becomes the \#1 New York Times bestseller.

My Name is Lucy Barton tells about a bond back parent-child relationship after years they have not met. The story is told backwards, starting with the adult child in the hospital when she was a young mother in the early 1980s. The adult child, Lucy, remembers her very first memories of her parents by feeling lonely. Then many years later, in the hospital, Lucy has grown up as adult children - as a wife and a 
mother, surprisingly her mother visits her, which is monumental because her mother and father live in impoverished conditions in a rural part of Illinois. Her mother hates hospitals but has come nonetheless, which speaks volumes to Lucy. From those explanations above, the writer finds dysfunctional family issues are needed to be discussed through this research.

This research gives more overview of real issues that commonly happen but rarely discussed in society through analysing this novel to find how dysfunctional families greatly impact children emotionally and physically until they are adults. Most previous studies rarely discuss dysfunctional families through literary works. One related previous study from a thesis conducted by (Alzoubi, 2016) entitled Bowen Family Systems Theory and Family Disintegration in Tennessee Williams's Drama shows the researcher more about how dysfunctional family examines the drama through developing how psychoanalytical theory has been used to gain a broader understanding about the life of a family after a postwar period. The difference here is, the researcher tries to analyze dysfunctional families in literary works from a novel, not a drama, which is a breakthrough of research on dysfunctional families.

This research also discusses how dysfunctional families affect the whole family members through My Name is Lucy Barton novel which an article by Hunt(2014) named Dysfunctional Family: Making Peace with Your Past helps the researcher to recognize that the dysfunctional family is separated into two forms: parents and children. This journal also helps to understand the reasons behind how dysfunctional families can happen and how it results on family members.

By understanding the difference between dysfunctional and healthy families, it is necessary to understand the family system the psychoanalysis theory, the researcher takes the previous studies from (Bowen, 2021) that is also helped by his assistant, Michael Kerr. Kerr and Bowen have been working together for 20 years. They published their psychological approach in analysis named Family System Theory. This journal provides information about the background of Bowen's family systems theory and how this theory helps the researcher to understand more about family member's behaviour in a better way.

One of the previous studies which help the researcher is Martin (2018)writings entitled The Effects of Growing Up in Dysfunctional Family. This writing helps the researcher to better analyze the behavioural impacts on children raised in dysfunctional families until they are adults and how they cope with that condition through the healing process.

Because of that, through this novel, we may understand how dysfunctional families affect children-parent relationships that impact real-life problems physically and emotionally. Therefore, the researcher is going to analyze the kind of dysfunctional family and its impact on Lucy Barton as the adult child in the novel: My Name is Lucy Barton to be aware of helping people suffering from their dysfunctional family, so the domestic violence and divorce number may lower down. 


\section{LITERATURE REVIEW}

\section{Theory of Literature}

My Name is Lucy Barton is a novel published in 2016 by Elizabeth Strout. It is the story about the life of a daughter named Lucy Barton living in a dysfunctional family since she was a kid. It impacts a lot when she grows up and starts her own family. In this novel, it is also shown how she survives from it and creates peace with her family and herself.

Literature has always been an object of study to learn human behaviour through the psychological condition, social problems, the personality of someone, history, culture, and others. (Wellek and Warren, 2014) explain that literature is one of imaginary works and performing various problems of humans and humanity in life. It is clear from the definition that literature is like a door to open the new world, to gain more new experience. It can be one of the greatest ways to deliver messages, express feelings, and even understand more about human life by creating various kinds of literary works. Those literary works may be short story, song, poetry, novel, drama, and many more. One of them which is commonly applied is a novel. Reading a literary work as a novel is one of the processes of interacting between an author and a reader - that is clear that, an author may be more able to deliver messages directly to the reader through literary works.

\section{A Brief View on Novel}

The word of the novel is from Italian, Novella which is from the plural of Latin Novellus, a new variant of Novus, which means "new". At first, the novel was popularly developed in America and England. It was developed in other forms of narrative non-fiction such as letters, biographies, and history. However, since the environment has been becoming more dynamic as well as society being concerned about different kinds of novels, it may change the basic concept of the original novel once it was developed. It is no more only about the reality of life, but also can be developed as fiction, imagination, and many more.

As its meaning, a novel gives new insight or experience to its readers and author. Nowadays, novels have been published on a lot of topics in various styles. Even (Wellek, 2014) believes that a novel is the portrayal of humans that is written by the author to the readers. It may be telling that life problems are covered in an amazing style of writing. It also can be in the form of fiction or nonfiction, but the long story delivered in the novel will always be impressive to the readers.

\section{A Brief View on Character}

Character is responsible for the thoughts and action in the works of literature, especially novels. Because of that, the character holds a significant role that may help to build and develop the storyline inside the novel.

According to (Banicky, 2017) states that "Character is personality evaluated, and personality is character devalued". The ideas and values can be seen through social life inside the novel. It shows that character is such a soul of the story itself.

In fiction literature, authors use various types of characters to narrate their stories. There are many types of characters that fulfill various roles in the narrative process. These are the general types of characters in fictional literature: 
a) Major, main or central characters are guides for the development and resolution of the conflict. There are two types of major characters, they are; 1) protagonist, and 2) antagonist.

b) Minor characters are the other characters that are less important than major but still have a large part in the story to create the plot and support the major characters. There are many kinds of minor characters, they are; 1) foil, 2) static and dynamic, 3) flat and round, and 4) stock.

\section{Psychology of Literature}

Both psychology and literature have deep concern in human life. While psychology is related to the study of observable patterns of human behaviour, literature shows how humans behave in facing problems and the environment. There are many kinds of literary works such as poems, short stories, novels, etc. So, it can be understood that literary works such as a novel, may portray the psychological condition of humans in real life towards kinship, friendship, and many more. Because through literary works, psychology can analyze through the psychology of the author, characters inside the literary works, even the readers by doing psychological inquiry. As (Kalat, 2021) explains that psychology is broadly defined as the scientific study of behaviour, both external observable action and internal thought which leads to experience.

Psychology and literature have familiar concepts. Psychology can clarify some literary problems, while literature presents psychological phenomena. To gain deeper and more understanding, literature can be studied by various approaches including psychological approaches. Dysfunctional family in this era is a phenomenon that involves many factors not only affects children but also other family members. Every single family has their problems and if those family members could not resolve the problems or find the right solution, with any kind of domestic violence, it can be said that the family is in a dysfunctional condition.

Based on the analysis of dysfunctional family, the researcher tries to analyze the kinds of a dysfunctional family and their behavioural impact on adult children: Lucy Barton in the novel: My Name is Lucy Barton. A dysfunctional family is considered a psychological problem because people are all interconnected by way of many kinds of interaction and behaviour. It is not only limited to the relationship between parents and children, but also with their siblings, neighbours, or any significant other. Nowadays, the dysfunctional family can be found in any level of family, whether rich or poor, privately or publicly happened in our daily life.

Related to the theory of the psychology of literature, the researcher will use the theory from (Bowen, 2021) in the Bowen Center for Study of Family. This theory explained the emotional system effects on psychological and cultural conditions of humans, which started in one's family. This psychoanalysis reflects the effects modern psychology has had upon literature and literary criticism. This theory is developed and helped by his assistant, Michael Kerr. Both Bowen and Kerr have worked together for twenty years.

This theory is a suitable tool for analyzing the modern form of American literature by developing how psychoanalytic theory has been used by literary critics to gain a broader understanding. This theory gives a modern paradigm for the conceptualization of human behaviour and treatment of human problems. It does not see the individual as an emotional 
unit or separate, and the individual as the basic unit of treatment. Bowen believes that individual functioning should be noticed in the context of relationships that each person's emotional functioning is closely interconnected with each other, and reciprocally impact on each other.

\section{Kinds of Dysfunctional Family}

According to Hunt (2014), dysfunctional families usually create rules which are dysfunctionally functional. Dysfunctional parents make the rules which work dysfunctionally and reinforce their children to obey them. It does not only remain in a family but the dysfunction spreads in every relationship of the children. Dysfunctional parents learn their behaviour unconsciously from their parents. They emulate and over-correct their dysfunctional parents.

This problem has inspired Elizabeth Strout to write a story about a dysfunctional family within a child until she becomes an adult. It was published in 2016 entitled My Name is Lucy Barton. It tells the story of a woman named Lucy Barton who has been a writer despite having left the world of her childhood behind almost full of the harrowing legacy of poverty and abuse. Elizabeth Strout writes My Name is Lucy Barton and gets predicate of \#1 New York Bestselling Novel, while there she discusses the difficulties that go hand in hand with dysfunctional families as well as emotional needs along with family members, especially mother and daughter. She discusses how talking about these issues out loud can lead to a more comfortable and open environment.

It is clear that in this dysfunctional family, children are forced to be grown-up too fast that may cause other mental health that they need to deal with. According to Hunt (2014) in Dysfunctional Family: Making Peace with Your Past, there are many kinds of a dysfunctional family which are separated into:

1. The controlling family is over controlling and overly old-fashioned. Parents criticize their children as punishment. They often underestimate through criticizing their child as verbal abuse that has long-lasting impacts. By criticizing harshly through their authoritative and dictatorial tone on the child's appearance, academic, skills, or basic value. They are very direct, while some use subtle putdowns disguised as humour. It makes the family members feel fearful and insensitive toward others.

2. The chaotic family is often found both household and individual are disorganized, dominated by a lot of problems which lead to indecisive and inconsistent parents and leave the children feeling abandoned. It results in the family members not being connected to each other.

3. The coddling family lacks parental authority. Disagreements are avoided and feelings are overprotected. It leads the parents to put much attention on their children. Family members here often find an undisciplined one.

4. The codependent family has strong conformity within the family but lacks selfdirection. Parents are over possessive that make their children feel smothered. It results in the family members being insecure. 


\section{Behavioural Impact of Dysfunctional Family}

Not only is it affected by the mental or psychological condition of a child, but the physical condition is also impacted by the dysfunctional family. Most children may do selfharming and self-blaming.

According to an American psychotherapist, (Martin, 2018) in The Effects of Growing Up in a Dysfunctional Family, dysfunctional families do not know how to behave healthily. Parents in dysfunctional families are commonly busy with their problems and neglecting their children. They take care of an addicted or dysfunctional partner so they do not have enough time, energy, or emotional intelligence to pay attention to, value, and support their children's feelings. In The Effects of Growing Up in a Dysfunctional Family by Martin (2018), the behavioural impacts of a dysfunctional family on the adult child are:

1. Children are difficult to trust others extends outside the family because some dysfunctional parents fail to protect their children, make them know how to survive in the unpredictable condition of their dysfunctional family,

2. Children often feel alone and hopeless because they think no one else is going through what they are experiencing in a dysfunctional family,

3. Children often feel inadequate and guilty by repressing their actual feelings about their parents. They avoid their true feelings by distracting from the pain when they see their parents angry or reheat them,

4. Children often feel highly anxious, sensitive, stressed, and unlovable because of the unpredictable and erratic condition of their parents, they have to take the role of miniature adults,

5. The self-esteem of children is damaged because they do not learn how to respect their feelings that may be continued as adults,

6. Self-blaming, because the family is disrupted with secrets and shame of their dysfunction that cause them to feel alone and hopeless because they do not have someone to talk to.

\section{RESEARCH METHOD}

The descriptive qualitative method is applied in doing this research. This method is a method of analysis by describing and analyzing the data and giving further explanation. Qualitative research according to (Lambert, 2012) is a study that summarizes the quality of relationships, activities, situations, or materials in everyday terms, comprehensively experienced individuals or groups of individuals. The descriptive method is applied in analyzing descriptive data. The researcher chooses a related text in Elizabeth Strout's My Name is Lucy Barton novel that is being analyzed.

Research is identical with data-in getting the right evidence and clues for the researcher to solve the problems of the study. There are two kinds of sources of data, they are primary and secondary data. The primary source of data for this study analysis was taken from My Name is Lucy Barton novel written by Elizabeth Strout. The secondary data can be 
taken from books, articles, journals or other sources of materials that related to the psychological approach-psychoanalysis or Dysfunctional Family. This data method is applied by understanding the psychological impacts on each family member from psychoanalysis theory and comprehends the symptoms and survival ways out from the dysfunctional family. The novel was published in 2016 by Random House. It contains 210 pages. Both data are taken in form of words as utterances, dialogues, and the protagonist's thoughts. The researcher only focused on data that indicates the kinds of dysfunctional families and their behavioural impacts faced by the adult child: Lucy Barton as the main character in the novel, and the healing process to overcome dysfunctional families.

The researcher collects all the data through some steps, first, collecting all the data needed. Second, reading the novel to understand fully the story and using some references. Third, organizing the data to ease the researcher can finally conduct and analyze the collected data and conclude the analysis.

In analyzing the data after all data collected, the researcher did some following steps as well. First, analyzing all selected data that relate to the theory from Sheryl Benton about the kinds of dysfunctional families and Sharon Martin about their behavioural impacts faced by the adult child: Lucy Barton. Second, describing the kinds of dysfunctional family and the behavioural impacts on adult children: Lucy Barton. And the last, conclude according to the formulated problems of study and using the descriptive qualitative method to describe the main data from the novel. Main data is presented in the form of quotations to prove the analysis.

\section{FINDINGS AND DISCUSSION}

\section{Finding}

\section{Kinds of Dysfunctional Family}

There are two out of four kinds of Dysfunctional Family in this novel, a theory by (Hunt, 2014) in Dysfunctional Family: Making Peace with Your Past, which are: The Controlling Family and The Chaotic Family.

\section{The Controlling Family}

"Otherwise, on occasion and without warning, my parents - and it was usually my mother and usually in the presence of our father - struck us impulsively and vigorously, as I think some people may have suspected by our splotchy skin and sullen dispositions."

(My Name is Lucy Barton; Elizabeth Strout: 12)

It is found the first kind of dysfunctional family in the novel My Name is Lucy Barton is the controlling family. Striking children impulsively and vigorously without any warnings because of parents' problems and cannot talk about it in any proper way-on any occasion is categorized as physical abuse. Someone who experiences physical abuse will feel really in sorrow or even have a long-lasting traumatic impact. Physical abuse is easy to be noticed by common people as Lucy is recognized by her neighbours as having splotchy skin and sullen dispositions as the result of physical abuse. Physical abuse makes the children feel fearful of their parents. 
Another one showing how The Controlling Family is not only shown from physical abuse but also verbal abuse. It does not only happen when Lucy has grown up. Even when Lucy was in elementary school, her mother often scolds her. As it is quoted below:

“... I said to her, "Mommy, do you know what we did to the Indians?" I said this slowly and with awe.

My mother wiped at her hair with the back of her hand. "I don't give a damn what we did to the Indians," she said.

(My Name is Lucy Barton; Elizabeth Strout: 71)

It is clear that Lucy's mother has been talking rudely to her child-that is categorized as the controlling family by overly criticizing. Lucy's mother is always busy with her work until it is easy for her to talk rudely to her child. Lucy's mother does not put too much attention to her children. As a child, it is normal for children to tell everything she has learned from school, even though it should be the parents' obligation to ask their children what they have been going through at school. However, in Lucy's family, when Lucy tries to communicate to her mother about something that takes her attention quite fully at school and shares it with her mother at home. Unfortunately, her mother is insensitive and talks rudely to Lucy. This controlling family defaults in negative impacts on a child's development and behaviour.

\section{The Chaotic Family}

"My family did not attend my wedding or acknowledge it, but when my first daughter was born I called my parents from New York, and my mother said she had dreamed it, so she already knew I had a baby girl, but she didn't know the name, and she seemed pleased with the name, Christina."

(My Name is Lucy Barton; Elizabeth Strout: 33)

The quotation above shows that her family is absent in her very special event, labelled as a chaotic family that Lucy has experienced. Relationships get better when both parties understand and care for each other. But in dysfunctional families, especially children who are experiencing chaotic families, they need to understand and fulfil their parents' emotional needs more than parents do. It is experienced by Lucy where she needs to understand her dysfunctional family more than her family understands her. That emotional absence is one of the chaotic family characteristics. Another condition where Lucy's parents are chaotic in her childhood is quoted below:

"I don't know, in numbers, how many times I was locked in the truck. I don't know the first time, I don't know the last time. But I was very young, probably no more than five years old the last time, otherwise, I'd have been in school all day. I was put there because my sister and brother were in school-this is my thought now-and my parents were both working. Other times I was put there as punishment."

(My Name is Lucy Barton; Elizabeth Strout: 58)

Lucy's parents' inadequacy to fulfill her emotional needs since she was a kid - that is affected Lucy who remembers how sorrowful and lonely her childhood was. Every child needs their parents' attention to feel safe and lovable that will affect their mental health. But 
in dysfunctional families - especially to those experiencing deficient parents, parental inadequacy to fulfill emotional needs is often found. Same as Lucy has been experienced from the quotation above. This inadequacy leaves Lucy's parents unable to take the role of parents who fulfill Lucy's emotional needs since her childhood due to a lot of problems they need to take care of more than their children's emotional needs which make both of them not feel connected to each other.

\section{Behavioural Impact of Dysfunctional Family}

There are three out of six Behavioral Impacts found in this novel, a theory by a psychotherapist Martin (2018) in The Effects of Growing Up in a Dysfunctional Family, which are:

\section{Feeling Lonely and Hopeless}

"I have met many people, even from the Midwest, who tell me that you can not hear the corn growing, and they are wrong. You cannot hear my heartbreaking, and I know that part is true, but to me, they are inseparable, the sound of growing corn and the sound of my heartbreaking."

(My Name is Lucy Barton; Elizabeth Strout: 59)

Lucy feels alone and hopeless from the quotation above. She feels no one understands how brokenhearted she was. Most children in dysfunctional families suffer from loneliness and hopelessness because none of their family members can fulfill their emotional needs and they cannot express their truest feelings such as crying when they feel sad, happy when having good times with others and share it with their family. This loneliness feeling is shown above as Lucy thinks no one has been going through what she has been going through as she was abandoned by her parents and siblings in her childhood by saying people cannot hear her heart is breaking. It is the most hurtful feeling of children who got impacted by dysfunctional families.

\section{Feeling Inadequate and Guilty}

"My mind went very strange places during these episodes of being in the truck... Then I would calm myself, and say aloud to myself, "It's okay, sweetie. A nice woman's going to come soon. And you're a very good girl, ..." I would have this fantasy, and it was very real to me, it kept me calm. I dreamed of not being cold, of having clean sheets, clean towels, a toilet that worked, and a sunny kitchen. ..."

(My Name is Lucy Barton; Elizabeth Strout: 60)

From the quotation above, it is shown that the behavioural impact of a dysfunctional family leaves Lucy feels inadequate and guilty. Children need to feel safe and loved in their own families. However, in a dysfunctional family, it children are hard to meet those primary feelings. It leaves them wondering if they have another family who loves them more than their parents and siblings do. This inadequate and guilty feeling leaves children in dysfunctional family numb or distracts their feelings continually. Same as Lucy, she creates her fantasy of having a better family because she feels her family doesn't love her. This kind of distraction is resulted in feeling inadequate and guilty in the family.

That unpredictable condition of her parents' behaviour often forces Lucy to repress 
her actual feeling about their parents. This condition also leaves her feeling guilty. As it is quoted below:

\begin{abstract}
"But with my mother, I didn't dare cry. Both my parents loathed the act of crying, and it's difficult for a child who is crying to have to stop, knowing if she doesn't stop everything will be made worse. This is not an easy position for any child. And my mother-that night in the hospital room - was the mother I had had all my life, no matter how different she seemed with her urgent quiet voice, her softer face. What I mean is, I tried not to cry."
\end{abstract}

(My Name is Lucy Barton; Elizabeth Strout: 100-101)

From the quotation above, it is shown that the guilty feeling resulted in repressing Lucy's feeling. In dysfunctional families, showing true feelings including crying are prohibited. This condition can be worse affected to a child's mental health until grown-up. This behaviour will result in difficulties to value them, noticing their feelings. It is normal for everyone to let all feelings come, including sadness that leads to crying. Crying does not mean someone is weak, but showing that we are human, having emotion is such gratitude. However, in Lucy's family, when she is crying in front of her parents it just makes the condition worse. As a child-Lucy needs to hold back her tears to not make her family condition worse as making her parent's great angry.

\title{
3. Feeling Unlovable
}

"William and I had a fight. Because I remember him saying, "Button, you just don't get it, do you?" He meant I did not understand that I could be loved, was loveable. Very often he said that when we had a fight."

(My Name is Lucy Barton; Elizabeth Strout: 119)

Feeling unlovable is the behavioural impact of the dysfunctional family experienced by Lucy. Feeling unlovable can happen because of many reasons, such as unable to recognize true feelings since kids where almost all children in dysfunctional families are experiencing it, including Lucy. This unlovable feeling leaves Lucy thinking that no one loves her, including her parents and her husband, even her children. When someone thinks that no one loves them and they could not speak their true feelings-leaving their relationship miscommunicated, that often leads to arguing. It also may be led into worse conditions such as separated, divorced - or the continual condition of dysfunctional families.

Another condition that portraying this behavioural impact of a dysfunctional family to Lucy Barton is quoted below:

"My mother was right; I had trouble in my marriage. And when my girls were nineteen and twenty years old, I left their father, and we have both remarried."

(My Name is Lucy Barton; Elizabeth Strout: 148-149)

It is clear from the quotation above that feeling unlovable since childhood that experienced by the parents may last for a child's life in starting their own family. It is shown from Lucy that even Lucy feels the same when she starts her own family, unlovable feelings still there in her life, emotional absence is still shown up. Whereas in a family, showing love 
and being compassionate, caring and putting attention to all family members is important. Because it will impact a child's behaviour until they are grown up.

\section{Discussion}

The research demonstrates the correlation between dysfunctional families affecting children's behaviour repetitively. The impact of the dysfunctional family makes endlessly the next generation of a dysfunctional family. However, based on the findings of similar studies, a more plausible explanation is a dysfunctional family can end when one of the family members opens up about the real thing happening within the family without feeling afraid or guilty. While previous research only provides kinds of dysfunctional family cases without showing the impact on children, or others showing the impacts of a dysfunctional family on children's behaviour without explaining the symptoms of a dysfunctional family which stimulates it. This research explains the kinds of dysfunctional families and how it impacts on children's behaviour.

In addition, most previous research showing the dysfunctional family often finds itself in a post-war condition. While in this research, the family is also portrayed post-war and affecting their children who have grown up in modern time in the 2010s. It is beyond the scope of this study to analyze dysfunctional families without post-war conditions within the family such as financial condition, affairs, etc.

Further studies should take into account the other phenomenon of a dysfunctional family that has not experienced the post-war condition within the family such as the psychological condition of each family members which hopes it can be found the real reason how dysfunctional family can be happened within the family and end it soon to create a healthy family which leads to better world condition.

\section{CONCLUSION}

After analyzing the novel some conclusions are drawn as follows: There are two kinds of dysfunctional family that Lucy Barton as an adult child experienced. The first is the controlling family where her parents often do physical and verbal abuse in showing their authority. The second is the chaotic family. Each dysfunctional family gives various impacts on Lucy Barton. The dysfunctional family also gives a behavioural impact on Lucy Barton's behaviour such as she often feels inadequate and guilty-leaves her represses her feelings, feels highly anxious, stressed. She also feels alone and hopeless leaves her feeling unlovable. Those behavioural impacts faced by the adult child - Lucy Barton are continued even when she grows up and has her own family. She finds it hard to trust others and feels that no one cares about her because she is craving emotional needs that she does not have since she was a kid from her parents - besides, her husband as well, and it leads her to be separated from him.

\section{BIBLIOGRAPHY}

Ahmadi, Anas. (2019). Metodologi Penelitian Sastra. Indonesia: Penerbit Graniti. Google Scholar

Alzoubi, Najah. (2016). Bowen Family Systems Theory and Family Disintegration in Tennessee Williams's Drama. UK: University of Leicester. Google Scholar 
Al Ubaidi BA. (2017). Cost of Growing up in Dysfunctional Family. J Fam Med Dis Prev 3:059. https://doi.org/10.23937/2469-5793/1510059

Banicki, Konrad. (2017). Theory \& Psychology: The Character-Personality Distinction: An historical, conceptual, and functional investigation. Poland: SAGE. https://doi.org/10.1177/0959354316684689

Bista, Bihungum. et.al. (2016). Psychosocial Problems among Adolescent Students: An Exploratory Study in The Central Region of Nepal. Nepal: Kathmandu University School of Nursing. Google Scholar

[CATAHU] Lembar Fakta dan Poin Kunci Catatan Tahunan Komnas Perempuan. (2018). Tergerusnya Ruang Aman Perempuan dalam Pusaran Politik Populisme. Jakarta: CATAHU. Google Scholar

Hunt, June. (2014). Dysfunctional Family: Making Peace with Your Past. USA: Rose Publishing Inc. Google Scholar

Kalat, James. (2021). Introduction to Psychology. Boston: Cengage. Google Scholar

Kerr, Michael; Bowen, Murray. (2009). Family Evaluation. Washington: W\&W Norton Company. Google Scholar

Lambert, Vickie; Lambert, Clinton. (2017). Pacific Rim International Journal of Nursing Research: Editorial: Qualitative Descriptive Research: An Acceptable Design. Thailand: Thai. Google Scholar

Martin, Sharon. (2018). The Effects of Growing Up in a Dysfunctional Family. San Jose: LCSW. Google Scholar

Muchtar, Muhizar. et.al. (2012). Pedoman Penulisan Skripsi. Medan: FIB USU. Google Scholar

Panggabean, Gabriella. (2018). The Impact of Bullying on Hannah Baker's Behavior in Jay Asher's 13 Reasons Why. Medan: FIB USU. Google Scholar

Sayer, A. (2017). Responding to the Troubled Families Programme: Framing the Injuries of Inequality. Social Policy and Society, 16(1), 155-164. https://doi.org/10.1017/S1474746416000373

Scholes, Lucy. (2018). A Quiet Novel Turned into A Forceful Performance. New York: The New York Review of Books. Google Scholar

Stoop, David; Masteller, James. (2011). Forgiving Our Parents, Forgiving Ourselves: Healing Adult Children of Dysfunctional Families. Tennessee: Regal. Google Scholar

Strout, Elizabeth. (2016). My Name is Lucy Barton. New York: Random House. Google Scholar

Titelman, Peter. (2014). Emotional Cutoff: Bowen Family Systems Theory Perspective. New York: The Haworth Clinical Practice Press. Google Scholar

Wellek, Rene and Warren, Austin. (2014). Theory of Literature. New York: Harcourt, Brace and Company, Inc. Google Scholar 